\title{
Persepsi Keadilan, Sistem Perpajakan dan Diskriminasi Terhadap Etika Penggelapan Pajak
}

\author{
Sekar Akrom Faradiza \\ Universitas Teknologi Yogyakarta \\ sekar.akrom@uty.ac.id
}

\begin{abstract}
Abstarct
The many cases of tax evasion in Indonesia have caused huge losses to the country. This causes tax evasion to be ethical or fair to do considering the many actions that should not be carried out by the tax apparatus. This study aims to examine whether the perception of justice, the taxation system and perceived discrimination by taxpayers can affect the perception of taxpayers on the tax evasion ethics. The data used in this study was obtained using a survey conducted to taxpayers registered in the tax service office in Yogyakarta and Central Java. Data analysis was performed using multiple linear regression analysis. The results of the study show that justice, taxation systems and discrimination affect the ethical perception of tax evasion.
\end{abstract}

Keywords: tax evasion, justice, taxation systems, discrimination

\begin{abstract}
Abstrak
Banyaknya kasus penggelapan pajak di Indonesia menyebabkan kerugian yang besar bagi negara. Hal ini menyebabkan tindakan penggelapan pajak menjadi etis atau wajar dilakukan mengingat banyaknya tindakan yang tidak seharusnya dilakukan oleh aparatur pajak. Penelitian ini bertujuan untuk menguji apakah persepsi keadilan, sistem perpajakan dan diskriminasi yang dirasakan oleh wajib pajak dapat mempengaruhi persepsi wajib pajak terhadap etika penggelapan pajak. Data yang digunakan dalam penelitian ini diperoleh menggunakan survei yang dilakukan kepada wajib pajak yang terdaftar di KPP wilayah Yogyakarta dan Jawa Tengah. Analisis data dilakukan dengan menggunakan analisis regresi linear berganda. Hasil penelitian menunjukkan bahwa keadilan, sistem perpajakan dan diskriminasi berpengaruh terhadap persepsi etika penggelapan pajak.
\end{abstract}

Kata kunci: penggelapan pajak, keadilan, sistem perpajakan, diskriminasi

Diterima: 9 Agustus 2018; Revisi: 2018; Disetujui: 2018 


\section{PENDAHULUAN}

Pajak merupakan sumber pendapatan bagi negara yang berfungsi untuk membiayai penyelenggaraan pemerintahan dan pembangunan yang digunakan sebesar-besarnya untuk kemakmuran rakyat. Fungsi tersebut disebut dengan fungsi budgetair. Dengan fungsi ini maka aparatur pajak akan berusaha untuk meningkatkan penerimaan negara sebanyak-banyaknya. Namun demikian penerimaan pajak tidak dapat mencapai target yang telah ditentukan. Hal ini dapat disebabkan adanya tindakan wajib pajak untuk meminimalkan pajak melalui berbagai cara salah satunya adalah dengan penggelapan pajak (tax evasion).

Penggelapan pajak (tax evasion) dan penghindaran pajak (tax avoidance) merupakan bagian dari perencanaan pajak (tax planning) yang bertujuan untuk mengurangi jumlah pembayaran pajak (Kurniawati dan Toly, 2014). Karakteristik keduanya sangat berbeda meskipun keduanya mempunyai tujuan yang sama. Penerapan penghindaran pajak sangat suli karena wajib pajak harus memiliki pemahaman peraturan perpajakan yang memadai. Hal ini mendorong wajib pajak lebih melakukan penggelapan pajak yaitu dengan melakukan penghematan pajak dengan cara-cara yang melanggar ketentuan pajak.

Penggelapan pajak merupakan serangkaian aktivitas yang dilakukan untuk menghindari pajak dan tidak sesuai dengan peraturan perpajakan (Palil et al., 2016; Mujiati dkk, 2017; Kurniawati dan Toly, 2014). Dalam penerapannya perilaku tersebut akan menjadi etis atau wajar untuk dilakukan mengingat banyaknya tindakan yang tidak seharusnya dilakukan oleh para pemimpin yaitu seperti menyalahgunakan dana pajak untuk kepentingan pribadi atau kelompok, tidak sistematisnya sistem perpajakan yang diterapkan dan adnaya peraturan perpajakan yang dianggap hanya menguntungkan satu pihak dan merugikan pihak lainnya. Hal-hal tersebut membuat wajib pajak tidak segan untuk melakukan penggelapan pajak karena mereka berasumsi bahwa pajak yang akan dibayarakan tidak akan dikelola dengan baik dan sehingga timbul anggapan perilaku tersebut etis dan wajar untuk dilakukan (Indriyani dkk, 2016). 
Penggelapan pajak di Indonesia sudah menjamur luas. Setiap tahun diperkirakan jumlah pajak yang dihindari sekitar Rp110 triliun yang dilakukan baik oleh wajib pajak orang pribadi maupun badan. Selama tahun 2010-2014 jumlah kerugian negara dan mengalir secara ilegal ke luar negeri mencapi Rp910 triliiun. Jumlah tersebut setara dengan $45 \%$ pertambahan jumlah uang beredar dalam peride yang sama di Indoensia yang jumlahnya Rp2.032 triliun (Himawan, 2017). Munculnya kasus-kasus tersebut memunculkan pemikiran negatif tentang pajak. Salah satunya dalam hal kepercayaan wajib pajak terhadap petugas pajak yang mulai menurun yang disebabkan karena uang atas pembayaran pajak yang dikeluarkan oleh wajib pajak ternyata disalahgunakan oleh petugas pajak yaitu masuk ke tabungan pribadi petugas pajak. Hal ini merupakan salah satu yang dapat mempengaruhi persepsi wajib pajak mengenai penggelapan pajak (tax evasion).

Persepsi wajib pajak mengenai tax evasion ini dapat terbentuk karena faktafakta yang ada tentang petugas pajak yang melakukan penggelapan, sehingga mereka memandang penggelapan pajak itu etis untuk dilakukan karena uang yang mereka bayarkan tidak digunakan untuk membiayai pengeluaran negara. Pengusaha umumnya menghindari pajak karena bagi perusahaan pajak adalah beban, dan banyak perusahaan yang melakukan tax planning untuk mengurangi pajak secara legal.

Banyaknya skandal dan kekacauan yang terjadi di institusi dan individu dalam bidang perpajakan merupakan akibat dari kegagalan etis/ethical failure (Hartman, 2008). Bahwa semua orang (pada posisi manapun) di sebuah institusi selalu menemui masalah yang menuntut keputusan yang bersifat etis. Dalam hal ini tindak penggelapan pajak akan dianggap menjadi suatu perbuatan yang etis dikarenakan buruknya birokrasi yang ada dan minimnya kesadaran hukum wajib pajak terhadap tindakan tersebut. Seperti halnya dengan penelitian yang dilakukan oleh McGee (2006) yang menjelaskan bahwa penggelapan pajak dianggap suatu hal yang etis dikarenakan oleh minimnya keadilan dalam penggunaan uang yang bersumber dari pajak, korupsi pemerintah, dan tidak mendapat imbalan/pengaruh 
atas pajak yang telah dibayarkan, yang berakibat kurangnya tingkat pendapatan penerimaan pajak negara dan menimbulkan krisis kepercayaan masyarakat kepada institusi terkait dalam membayarkan pajaknya.

Salah satu asas perpajakan yang penting adalah keadilan. Sistem perpajakan yang adil merupakan reward bagi wajib pajak, karena wajib pajak akan merasa dihargai sehingga wajib pajak mempunyai kecenderungan melakukan kewajiban perpajakannya dengan benar. Mengingat pentingnya penerimaan pajak terhadap pembangunan nasional, morat Jenderal Pajak sebagai instansi pemerintah unit dalam organisasi Departemen Keuangan yang ditugasi menangani masalah pajak telah berusaha untuk mengemban tugas tersebut dengan sebaik baiknya melalui pelaksanaan program intensifikasi dan ekstensifikasi dalam bidang perpajakan. Pelaksanaan program tersebut diupayakan dapat berjalan secara terintegrasi, yaitu dapat berjalan lancar dan berkesinambungan.

Sistem pemungutan pajak merupakan salah satu elemen penting yang menunjang keberhasilan pemungutan pajak suatu negara. Secara umum terdapat tiga sistem pemungutan pajak, yaitu official assessment system, self assessment system, dan withholding system. Reformasi perpajakan di Indonesia yang dimulai tahun 1984, memperkenalkan self assessment system yaitu setiap wajib pajak diberi kepercayaan untuk mendaftarkan diri, menghitung hutang pajaknya sendiri dan melaporkan hasil perhitungan pajaknya ke Kantor Pelayanan Pajak. Sehingga aparat pajak hanya mengawasi, melakukan pelayanan dan penyuluhan kepada wajib pajak. Oleh karena itu, sistem ini akan berjalan dengan baik apabila masyarakat memiliki tingkat kesadaran perpajakan yang tinggi. Keberhasilan self assessment system ini tidak dapat tercapai tanpa adanya kerjasama yang baik antara fiskus dan wajib pajak. Faktor utama penentu keberhasilan self assessment system ini adalah terwujudnya kesadaran dan kejujuran dari masyarakat khususnya wajib pajak dalam melaksanakan kewajiban perpajakan sesuai dengan ketentuan yang berlaku.

Undang-undang No. 39 Tahun 1999 tentang Hak Asasi Manusia Pasal 1 ayaat (3), diskriminasi adalah setiap pembatasan, pelecehan atau pengucilan yang 
langsung ataupun tidak langsung didasarkan pada pembedaan manusia atas dasar agama, suku, ras, etnik, kelompok, golongan, status social, status ekonomi, jenis kelamin, bahasa, keyakinan politik, yang berakibat pengurangan, penyimpangan atau penghapusan pengakuan, pelaksanaan, atau penggunaan hak asasi manusia dan kebebasan dasar dalam kehidupan baik individual maupun kolektif dalam bidang politik, ekonomi, hukum, social, budaya dan aspek kehidupan lainnya. Ketika diskriminasi dilakukan oleh aparatur pajak, maka akan muncul pola piker yang buruk tehadap aparatur pajak sehingga wajib pajak tergerak untuk melakukan tindakan penggelapan pajak dan menganggap hal tersebut etis untuk dilakukan (Widjaja dkk, 2017).

Suminarsasi dan Supriyadi (2011) melakukan penelitian tentang pengaruh keadilan, sistem perpajakan, dan diskriminasi terhadap persepsi wajib pajak mengenai etika penggelapan pajak pada wajib pajak pribadi di Daerah Istimewa Yogyakarta. Hasil penelitian menunjukkan bahwa penggelapan pajak dapat dipandang sebagai suatu hal yang etis dan juga tidak etis. Dalam penelitian tersebut variabel keadilan tidak berpengaruh signifikan terhadap persepsi wajib pajak mengenai etika penggelapan pajak. Sedangkan sistem perpajakan dan diskriminasi berpengaruh positif terhadap persepsi wajib pajak mengenai etika penggelapan pajak. Semakin tinggi persepsi wajib pajak terhadap sistem perpajakan dan tingkat diskriminasi dalam perpajakan, maka perilaku penggelapan pajak cenderung dianggap sebagai perilaku yang etis.

Menurut Mardiasmo (2009) sesuai dengan tujuan hukum, yakni mencapai keadilan, undang-undang dan pelaksanaan pemungutan pajak harus adil. Adil dalam perundang-undang diantaranya mengenakan pajak secara umum dan merata, serta disesuaikan dengan kemampuan masing-masing. Sedangkan adil dalam pelaksanaannya yakni dengan memberikan hak kepada wajib pajak untuk mengajukan keberatan, penundaan dalam pembayaran dan mengajukan banding kepada Majelis Pertimbangan Pajak. Sebagaimana penelitian yang dilakukan oleh Suminarsasi dan Supriyadi (2011) menunjukan adanya pengaruh positif keadilan terhadap persepsi etis wajib pajak mengenai etika penggelapan pajak. 
Penelitian McGee (2006) mengemukakan pandangan mengenai penggelapan pajak menurut hasil penelitiannya penggelapan pajak dipandang sebagai perilaku yang tidak pernah beretika. Selain itu, penelitian yang dilakukan McGee et al. (2008) yang dilakukan di Hongkong dan Amerika juga menghasilkan dampak yang sama bahwa variabel keadilan memiliki pengaruh yang kuat terhadap etika penggelapan pajak. Alasan-alasan yang mendukung pandangan ini antara lain bahwa setiap masyarakat mempunyai kewajiban kepada negaranya untuk membayar pajak. Dalam penelitian yang dilakukan oleh Nickerson et al. (2009) juga mendukung variabel keadilan yang mempengaruhi persepsi Wajib pajak terhadap etika penggelapan pajak. Adanya berbagai pemikiran tentang pentingnya keadilan bagi seseorang termasuk dalam pembayaran pajak juga akan mempengaruhi sikap mereka dalam melakukan pembayaran pajak.

Sistem perpajakan yang sudah ada dan diterapkan selama ini menjadi acuan oleh wajib pajak dalam memenuhi kewajiban perpajakannya. Keberhasilan sistem tersebut tidak dapat tercapai tanpa adanya kerjasama yang terjalin dengan baik antara fiskus dan wajib pajak. Apabila sistem yang ada dirasa sudah cukup baik dan sesuai dalam penerapannya, maka wajib pajak akan memberikan respon yang baik dan taat pada sistem yang ada dalam memenuhi kewajiban perpajakannya, tetapi jika hal sebaliknya yang terjadi karena wajib pajak merasa bahwa sistem pajak yang ada belum cukup baik mengakomodir segala kepentingannya, maka wajib pajak akan menurunkan tingkat kepatuhan atau menghindar dari kewajiban perpajakannya.

Hasil penelitian Abrahams dan Kristanto (2016) menunjukkan bahwa responden tidak setuju dengan tindakan penggelapan pajak meskipun sistem perpajakan tidak berjalan dengan baik. Sistem perpajakan yang dikatakan tidak baik adalah ketika pengelolaan uang pajak yang tidak dapat dipertanggungjawabkan, petugas pajak yang tidak kompeten dan korup juga prosedur perpajakan yang berbelit-belit. Dalam penelitian Supriyadi dan Suminarsasi (2011) menunjukkan bahwa sistem perpajakan berpengaruh secara negatif terhadap persepsi wajib pajak mengenai etika penggelapan pajak. Hal ini 
berarti para wajib pajak menganggap bahwa semakin baik sistem perpajakannya maka perilaku penggelapan pajak dianggap sebagai perilaku yang tidak etis. Akan tetapi apabila sistem perpajakannya semakin tidak bagus, maka perilaku penggelapan pajak dianggap sebagai perilaku yang cenderung etis.

Menurut Danandjaja (2003) diskriminasi adalah perlakuan yang tidak seimbang terhadap perorangan, atau kelompok, berdasarkan sesuatu, biasanya bersifat kategorikal, atau atribut-atribut khas, seperti berdasarkan ras, kesukubangsaan, agama, atau keanggotaan kelas-kelas sosial. Perilaku diskriminasi dalam hal perpajakan ini merupakan tindakan yang menyebabkan keengganan masyarakat/WP (baik domestik dan asing) dalam memenuhi kewajiban perpajakannya. Misalnya perlakuan diskriminasi pajak pada investor asing (konstruksi dan manufaktur) yang menanamkan modalnya di Indonesia, dimana para investor dikenakan tarif pajak yang tinggi sebesar 30\% dibandingkan negara ASIA lainnya (Malaysia, Thailand dll) yang menimbulkan para investor yang ingin menanamkan modalnya di Indonesia menjadi enggan.

Penelitian yang dilakukan Suminarsasi dan Supriyadi (2011) membuktikan jika diskriminasi berpengaruh positif terhadap persepsi mengenai etika penggelapan pajak. Semakin tinggi tingkat diskriminasi maka perilaku penggelapan pajak dipandang sebagai perilaku yang cenderung etis, sebaliknya jika semakin rendah tingkat diskriminasi maka perilaku penggelapan pajak dipandang sebagai perilaku yang tidak etis. Penelitian ini juga sejalan dengan yang dilakukan oleh Nickerson et al. (2009) yang mengindikasikan bahwa diskriminasi berpengaruh positif terkait dengan etika penggelapan pajak. Penelitian yang dilakukan oleh McGee et al. (2008) juga menghasilkan bahwa diskriminasi berpengaruh terhadap etika penggelapan pajak. Jadi, apabila semakin tinggi tingkat diskriminasi dalam perpajakan maka perilaku penggelapan pajak cenderung dianggap sebagai perilaku yang etis.

Penelitian ini ingin menguji pengaruh persepsi keadilan, sistem perpajakan dan diskriminasi terhadap etika penggelapan pajak. Hal ini penting untuk dilakukan mengingat maraknya tindakan penggelapan pajak yang banyak 
dilakukan wajib pajak dan kerugian besar yang ditimbulkan atas tindakan tersebut. Penelitian ini diharapkan dapat memberikan masukan bagi sistem perpajakan sehingga dapat meningkatkan kesadaran dan mengurangi dan bahkan menghilangkan tindakan penggelapan pajak yang dilakukan oleh wajib pajak.

\section{METODE}

Populasi dalam penelitian ini berupa Wajib Pajak Orang Pribadi dan Badan yang berada pada Kantor Pelayanan Pajak di daerah Yogyakarta dan Jawa Tengah. Populasi bukan hanya orang, tetapi juga obyek dan benda-benda alam yang lain. Populasi juga bukan sekedar jumlah yang ada pada objek/subjek yang dipelajari, tetapi meliputi seluruh karakteristik/sifat yang dimiliki oleh subjek atau objek yang diteliti itu. Sampel yang diambil yaitu Wajib Pajak Orang Pribadi dan Badan yang terdaftar pada 4 Kantor Pelayanan Pajak (KPP) yang ada di Wilayah Yogyakarta dan beberapa di wilayah Jawa Tengah. Pemilihan sampel ini dipilih karena peneliti ingin mengetahui informasi yang berkaitan tentang persepsi wajib pajak mengenai etika penggelapan pajak, maka peneliti memilih wajib pajak orang pribadi dan badan sebagai sampel penelitian.

Penelitian ini dilakukan dengan menggunakan metode survey. Data utama penelitian ini diperoleh melalui penelitian lapangan, peneliti memperoleh data langsung dari pihak pertama (data primer). Pada penelitian ini, yang menjadi subyek penelitian adalah wajib pajak pribadi dan badan yang terdaftar di KPP tersebut. Metode pengumpulan data kuesioner dilakukan dengan teknik personally administered questionnaires, yaitu kuisioner disampaikan dan dikumpulkan langsung oleh peneliti. Pengambilan sampel dilakukan dengan metode convenience sampling, yaitu pengambilan sampel secara nyaman dilakukan dengan memilih sampel bebas sekehendak perisetnya (Jogiyanto, 2010), dengan kriteria sampel wajib pajak orang pribadi dan badan yang mempunyai NPWP. Teknik pemilihan sampel ini dipilih karena pertimbangan lokasi yang mudah untuk dijangkau sehingga dapat memudahkan peneliti dalam pengumpulan sampel yang akan digunakan dalam penelitian ini. 
Validitas adalah ketepatan atau kecermat suatu instrumen dalam pengukuran. Validitas menunjukkan seberapa nyata suatu pengujian mengukur apa yang seharusnya diukur. Validitas berhubungan dengan ketepatan alat ukur untuk melakukan tugasnya mencapai sasarannya. Uji validitas dalam penelitian ini menggunakan analisis faktor dengan loading factor 0,50, artinya jika hasil pengujian setiap item pertanyaan memiliki loading factor lebih dari 0,50 atau sama dengan 0,50 berarti item pertanyaan tersebut valid.

Uji reliabilitas digunakan untuk mengetahui konsistensi alat ukur, apakah alat pengukur yang digunakan dapat diandalkan dan tetap konsistensi jika pengukurannya tersebut diulang. Reliabilitas menunjukkan akurasi dan ketepatan dari pengukurnya. Reliabilitas berhubungan dengan konsistensi dari pengukur. Suatu pengukur dikatakan reliabel (dapat diandalkan) jika dapat dipercaya. Peneliti melakukan uji reliabilitas dengan menghitung cronbach's alpha dari masing-masing instrume dalam suatu variabel instrument. Metode cronbach's alpha sangat cocok digunakan pada skor yang berbentuk skala. Suatu variabel dikatakan reliabel jika memberikan cronbach alpha $>0,5$.

Analisis yang digunakan dalam penelitian adalah analisis regresi linear berganda. Analisis regresi linear berganda adalah regresi yang melibatkan hubungan antara tiga variabel atau lebih. Dalam analisis regresi yang ingin diperoleh adalah ada tidaknya hubungan sebab akibat antara variabel-variabel tersebut, variabel yang menyebabkan terjadinya perubahan terhadap variabel lain biasanya disebut variabel yang independen (variabel bebas), sedangkan variabel yang terkena pengaruh atau bergantung terhadap variabel lain, biasanya disebut variabel dependen. Model regresi yang digunakan dalam penelitian ini adalah:

$$
E P P=\alpha+\beta_{1} K+\beta_{2} S P+\beta_{3} D+\varepsilon
$$

\section{Keterangan:}

EPP : Etika Penggelapan Pajak

K : Keadilan

SP : Sistem Perpajakan 


$\begin{array}{ll}D & \text { : Diskriminasi } \\ \alpha & : \text { Konstanta } \\ \beta & : \text { koefisien regresi } \\ \varepsilon & : \text { error }\end{array}$

\section{HASIL DAN PEMBAHASAN}

Data penelitian ini diperoleh dengan menggunakan kuesioner yang telah disebar kepada Wajib Pajak Pribadi dan Badan yang terdaftar pada Kantor Pelayanan Pajak (KPP) Pratama di wilayah Yogyakarta dan Jawa Tengah II. Jumlah kuesioner yang disebar berjumlah 190 eksemplar dan jumlah yang kembali sebanyak 190 eksemplar atau 100\%, sedangkan kuesioner yang dapat diolah adalah sebanyak 186 atau 98\%. Berikut ini adalah rincian sampel:

Tabel 1. Sampel Penelitian

\begin{tabular}{clcc}
\hline No & \multicolumn{1}{c}{ Keterangan } & Jumlah & Presentase (\%) \\
\hline 1 & Kuesioner yang disebar & 190 & $100 \%$ \\
2 & Kuesioner yang tidak kembali & 0 & $0 \%$ \\
3 & Kuesioner yang tidak dapat diolah & 4 & $2 \%$ \\
4 & Kuesioner yang dapat diolah & 186 & $98 \%$ \\
\hline
\end{tabular}

Berdasarkan tabel 1 diketahui terdapat 4 kuesioner yang tidak dapat diolah karena jawaban tidak lengkap yang berasal dari KPP Pratama Yogyakarta dan KPP Pratama Sukoharjo masing-masing 2 kuesioner.

Berdasarkan tabel 2 diketahui responden wanita lebih mendominasi yaitu sebanyak 101 responden atau 54,3\% sisanya adalah pria. Hal ini menggambarkan wajib pajak yang melakukan pelaporan pajak didominasi oleh wanita dibandingkan pria. Berikut ini adalah demografi sampel berdasarkan jenis kelamin responden:

Tabel 2. Proporsi Responden Berdasarkan Jenis Kelamin

\begin{tabular}{|c|c|c|}
\hline Jenis Kelamin & Jumlah & Presentase (\%) \\
\hline Wanita & 101 & $54,3 \%$ \\
\hline Pria & 85 & $45,7 \%$ \\
\hline Total & 186 & $100 \%$ \\
\hline
\end{tabular}


Berdasarkan tabel 3 terlihat bahwa wajib pajak yang melakukan pelaporan pajak rata-rata adalah berusia 20-30 tahun yaitu sebanyak 74 atau $39,8 \%$ responden. Berikut ini adalah demografi sampel berdasarkan umur responden:

Tabel 3. Proporsi Responden Berdasarkan Umur

\begin{tabular}{ccc}
\hline \multicolumn{1}{c}{ Umur Responden } & Jumlah & Presentase (\%) \\
\hline 20-30 tahun & 74 & $39,8 \%$ \\
30-40 tahun & 56 & $30,1 \%$ \\
40-50 tahun & 42 & $22,6 \%$ \\
$>50$ tahun & 14 & $7,5 \%$ \\
\hline Total & $\mathbf{1 8 6}$ & $\mathbf{1 0 0 \%}$ \\
\hline
\end{tabular}

Berdasarkan tabel 4 diketahui bahwa sebanyak 118 orang atau 63,4\% responden berpendidikan S1. Berikut ini adalah demografi sampel berdasarkan pendidikan terakhir responden:

\begin{tabular}{|c|c|c|}
\hline Pendidikan Terakhir & Jumlah & $\begin{array}{c}\text { Presentase } \\
(\%)\end{array}$ \\
\hline D3 & 27 & $14,5 \%$ \\
\hline S1 & 118 & $63,4 \%$ \\
\hline S2 & 9 & $4,8 \%$ \\
\hline S3 & 0 & $0 \%$ \\
\hline Lainnya & 32 & $17,2 \%$ \\
\hline Total & 186 & $100 \%$ \\
\hline
\end{tabular}

Berdasarkan tabel 5 diketahui 64\% atau 119 responden adalah wajib pajak orang pribadi dan sisanya adalah wajib pajak badan.

Tabel 5. Proporsi Responden Berdasarkan Jenis Wajib Pajak

\begin{tabular}{|c|c|c|}
\hline Wajib Pajak & Jumlah & Presentase (\%) \\
\hline Orang Pribadi & 119 & $64 \%$ \\
\hline Badan & 67 & $36 \%$ \\
\hline Total & 186 & $100 \%$ \\
\hline
\end{tabular}

Berdasarkan hasil uji validitas dengan analisis faktor, diketahui bahwa setiap item pertanyaan yang digunakan untuk mengukur keadilan memiliki nilai loading factor lebih dari 0,50. Hal ini menunjukkan bahwa seluruh item pertanyaan valid. Sedangkan hasil pengujian reliabilitas pada variabel keadilan memiliki nilai 
cronbach's alpha lebih dari 0,5 yaitu 0,833. Sehingga dapat disimpulkan bahwa item pertanyaan reliabel. Berikut ini hasil uji validitas dan reliabiltias pada variabel keadilan:

\begin{tabular}{cccc}
\multicolumn{4}{c}{ Tabel 6. Hasil Uji Validitas dan Reliabilitas Variabel Keadilan } \\
\hline Pertanyaan & Loading Factor & Hasil & Cronbach's Alpha \\
\hline Keadilan 1 & 0,838 & Valid & \\
Keadilan 2 & 0,889 & Valid & \\
Keadilan 3 & 0,835 & Valid & \multirow{2}{*}{0,833} \\
Keadilan 4 & 0,765 & Valid & \\
Keadilan 5 & 0,647 & Valid & \\
Keadilan 6 & 0,622 & Valid & \\
\hline
\end{tabular}

Hasil uji validitas diketahui terdapat dua item pertanyaan dari variabel sistem perpajakan yang tidak valid karena memiliki factor loading di bawah 0,5. Sehingga untuk analisis selanjutnya hanya digunakan 3 item pertanyaan yang digunakan untuk mengukur variabel ini. Sedangkan hasil uji reliabilitas menunjukkan nilai cronbach's alpha lebih dari 0,5 yaitu 0,695. Berikut ini disajikan secara lengkap hasil uji validitas dan reliabilitas variabel sistem perpajakan:

Tabel 7. Hasil Uji Validitas dan Reliabilitas Variabel Sistem Perpajakan

\begin{tabular}{cccc}
\hline Pertanyaan & Loading Factor & Hasil & Cronbach's Alpha \\
\hline Sistem Perpajakan 3 & 0,549 & Valid & 0,695 \\
Sistem Perpajakan 4 & 0,903 & Valid & \\
Sistem Perpajakan 5 & 0,866 & Valid & \\
\hline
\end{tabular}

Hasil analisis faktor menunjukkan bahwa seluruh item pertanyaan yang digunakan untuk mengukur variabel diskriminasi valid karena memiliki factor loading di atas 0,5. Nilai cronbach's alpha sebesar 0,530 artinya kuisioner tersebut reliabel. Berikut ini disajikan hasil pengujian tersebut:

Tabel 8. Hasil Uji Validitas dan Reliabilitas Variabel Diskriminasi

\begin{tabular}{cccc}
\hline Pertanyaan & Loading Factor & Hasil & Cronbach's Alpha \\
\hline Diskriminasi 1 & 0,769 & Valid & 0,530 \\
Diskriminasi 2 & 0,842 & Valid & \\
Diskriminasi 3 & 0,790 & Valid & \\
Diskriminasi 4 & 0,583 & Valid & \\
\hline
\end{tabular}


Berdasarkan hasil uji validitas terhadap variabel persepsi etika penggelapan pajak diketahui bahwa seluruh item pertanyaan valid karena memiliki factor loading di atas 0,50. Hasil uji reliabilitas juga menunjukkan bahwa kuisioner reliabel dengan nilai Croncbach's Alpha di atas 0,50 yaitu sebesar 0,697. Berikut ini disajikan hasil uji validitas dan reliabilitas:

Tabel 9. Hasil Uji Validitas dan Reliabilitas Variabel Etika Penggelapan Pajak

\begin{tabular}{cccc}
\hline Pertanyaan & Loading Factor & Hasil & Croncbach's Alpha \\
\hline Penggelapan Pajak 1 & 0,789 & Valid & 0,697 \\
Penggelapan Pajak 2 & 0,824 & Valid & \\
Penggelapan Pajak 3 & 0,765 & Valid & \\
Penggelapan Pajak 4 & 0,755 & Valid & \\
Penggelapan Pajak 5 & 0,852 & Valid & \\
Penggelapan Pajak 6 & 0,649 & Valid & \\
Penggelapan Pajak 7 & 0,689 & Valid & \\
Penggelapan Pajak 8 & 0,600 & Valid & \\
\hline
\end{tabular}

Uji $\mathrm{F}$ atau uji model dilakukan untuk menguji apakah model penelitian layak untuk digunakan. Hasil analisis uji F disajikan pada tabel berikut ini:

Tabel 10. Hasil Uji F

\begin{tabular}{llrrrrr}
\hline \multirow{2}{*}{ Model } & $\begin{array}{c}\text { Sum of } \\
\text { Squares }\end{array}$ & df & $\begin{array}{c}\text { Mean } \\
\text { Square }\end{array}$ & \multicolumn{1}{c}{$\boldsymbol{F}$} & Sig. \\
\hline 1 & Regression & 1496.918 & 3 & 498.973 & 30.943 & $.000^{a}$ \\
& Residual & 2934.867 & 182 & 16.126 & & \\
& Total & 4431.785 & 185 & & & \\
\cline { 2 - 7 }
\end{tabular}

Dari hasil analisis regresi dilakukan perhitungan koefisien determinasi untuk mengukur seberapa besar pengaruh variabel keadilan, sistem perpajakan dan diskriminasi terhadap penggelapan pajak. Berdasarkan tabel di bawah ini dapat diketahui bahwa nilai Adjusted $R$ Square sebesar 0,327 yang berarti variabel keadilan, sistem perpajakan dan diskriminasi dapat menjelaskan persepsi penggelapan pajak sebesar $32,7 \%$ dan sisanya dijelaskan oleh factor lain yang 

Pajak

tidak dimasukkan dalam penelitian ini. Berikut ini disajikan hasil uji koefisien determinasi:

Tabel 11. Hasil Uji Koefisien Determinasi

\begin{tabular}{cccc} 
Model & R & R Square & $\begin{array}{c}\text { Adjusted R } \\
\text { Square }\end{array}$ \\
\hline 1 & $.581^{\text {a }}$ & .338 & .327 \\
\hline
\end{tabular}

Uji ini berguna untuk menguji pengaruh dari masing-masing variabel independen terhadap variabel dependen. Untuk mengetahui ada tidaknya pengaruh masing- masing variabel independen terhadap variabel dependen dapat dilihat pada tingkat signifikansi 0,05. Hasil uji dapat dilihat pada tabel 13, jika nilai probability $\mathrm{t}<0,05$ maka Ha diterima, sedangkan jika nilai probability $\mathrm{t}>0,05$ maka Ha tidak didukung.

Tabel 12. Hasil Uji Regresi Liniear Berganda

\begin{tabular}{|c|c|c|c|c|c|c|}
\hline & \multirow[t]{2}{*}{ Model } & \multicolumn{2}{|c|}{$\begin{array}{c}\text { Unstandardized } \\
\text { Coefficients }\end{array}$} & \multirow{2}{*}{$\begin{array}{c}\text { Standardized } \\
\text { Coefficients }\end{array}$} & \multirow[t]{2}{*}{$T$} & \multirow[t]{2}{*}{ Sig. } \\
\hline & & $B$ & Std. Error & & & \\
\hline \multirow[t]{4}{*}{1} & (Constant) & 8.845 & 1.896 & & 4.665 & .000 \\
\hline & Keadilan & .394 & .099 & .282 & 3.990 & .000 \\
\hline & Sistem Perpajakan & .420 & .115 & .238 & 3.650 & .000 \\
\hline & Diskriminasi & .452 & .131 & .239 & 3.451 & .001 \\
\hline
\end{tabular}

Hasil uji hipotesis menunjukkan tingkat signifikasi variabel keadilan sebesar 0,000 yang berarti $\mathrm{H}_{\mathrm{a} 1}$ diterima sehingga dapat dikatakan bahwa keadilan berpengaruh signifikan terhadap penggelapan pajak. Nilai koefisien bertanda positif artinya keadilan berpengaruh positif terhadap persepsi wajib pajak mengenai etika penggelapan pajak. Hasil penelitian ini konsisten dengan penelitian yang dilakukan McGee (2008), Nickerson et al. (2009), Suminarsasi dan Supriyadi (2011).

Penggelapan pajak dianggap suatu hal yang etis ataupun tidak etis tergantung bagaimana persepsi wajib pajak terhadap keadilan pelaksanaan perpajakan. Dalam hal ini berkaitan dengan tinggi rendahnya tarif pajak yang 
berlaku dan bagaimana pemerintah mengelola dana yang bersumber dari pajak. Apabila wajib pajak menilai bahwa pajak telah dikelola secara adil maka wajib pajak menganggap bahwa penggelapan pajak tidak etis untuk dilakukan dan sebaliknya. Hal ini membuktikan bahwa semakin tinggi persepsi keadilan, maka persepsi wajib pajak mengenai etika penggelapan pajak semakin tinggi. Sehingga pemerintah perlu meningkatkan keadilan yang berkaitan dengan penggunaan dana yang bersumber dari pajak secara adil dan merata. Hasil penelitian sesuai dengan penelitian yang dilakukan Suminarsasi dan Supriyadi (2011). Hasil penelitian ini bertentangan dengan hasil penelitian yang telah dilakukan (Indriyani dkk, 2016; Mujiyati dkk, 2017; Kurniawai dan Toly, 2014) dan menemukan bahwa keadilan berpengaruh negatif terhadap persepsi etika penggelapan pajak.

Implikasi dari penelitian ini bahwa pemerintah harus mengantisipasi masalah yang sangat mendasar yang selalu dijumpai dalam pemungutan dan pengalokasian dana pajak, yaitu bagaimanakah cara mewujudkan keadilan pajak, hal ini tidak mudah diterapkan karena keadilan memiliki perspektif yang sangat luas, dan masing-masing individu menilainya berbeda-beda (Siahaan, 2010). Setidaknya ada tiga aspek keadilan yang perlu diperhatikan dalam penerapan pajak, yaitu: pertama, keadilan dalam penyusunan undang-undang pajak. Kedua, keadilan dalam penerapan ketentuan perpajakan yang merupakan hal yang harus diperhatikan benar oleh negara/pemerintah sebagai pihak yang diberi kewenangan oleh hukum pajak untuk menarik/memungut pajak dari masyarakat. Ketiga, keadilan dalam penggunaan uang pajak yang menjadi tolok ukur penerapan keadilan perpajakan, berkaitan dengan harapan sampai dimana manfaat dari pemungutan pajak tersebut dipergunakan untuk kepentingan masyarakat banyak. Hal ini menunjukkan bahwa pemerintah harus lebih baik dalam mengawasi, mengakomodir, mendistribusikan dan mengolah dana pajak yang ada, sehingga dapat mewujudkan pembangunan yang adil dan merata.

Pengujian terhadap $\mathrm{H}_{\mathrm{a} 2}$ menunjukkan bahwa sistem perpajakan berpengaruh terhadap persepsi etika penggelapan pajak sehingga dapat disimpulkan bahwa $\mathrm{H}_{\mathrm{a} 2}$ diterima. Arah koefisien adalah positif yang artinya sistem 
perpajakan berpengaruh positif terhadap persepsi wajib pajak mengenai etika penggelapan pajak. Hasil penelitian ini konsisten dengan penelitian yang dilakukan oleh McGee (2008), Nickerson et al. (2009) dan Suminarsasi dan Supriyadi (2011).

Penggelapan pajak dianggap suatu hal yang etis tergantung bagaimana persepsi wajib pajak terhadap sistem perpajakan yang ada. Hal ini terkait dengan tarif pajak yang dikenakan kepada wajib pajak yang disesuaikan dengan tingkat penghasilan sehingga akan tercipta sistem perpajakan yang adil. Semakin baik, mudah dan terkendali prosedur sistem perpajakan yang diterapkan, maka tindak penggelapan pajak dianggap sebagai suatu tindakan yang tidak etis. Menurut Undang-undang Nomor 28 Tahun 2007 tentang Ketentuan Umum dan Tata Cara Perpajakan sistem pemungutan pajak di Indonesia memiliki corak dan ciri tersendiri dengan menganut self assessment system dimana masyarakat diberikan kepercayaan penuh untuk menghitung, memperhitungkan, menyetor serta melaporkan kewajiban pajaknya, dan menunjukan sifat kegotongroyongan pajak sebagai wujud kewajiban kenegaraan setiap anggota masyarakat. Hasil penelitian menyatakan bahwa terdapat pengaruh positif antara sistem perpajakan terhadap etika penggelapan pajak. Hal ini membuktikan bahwa semakin baiknya sistem perpajakan, maka persepsi wajib pajak mengenai penggelapan pajak dipandang sebagai perilaku yang cenderung etis.

Implikasinya bahwa akses kemudahan sistem perpajakan yang ada, baik dalam hal pembayaran dan pelaporan SPT (Surat Pemberitahuan Tahunan) diharapkan dapat membuat masyarakat atau wajib pajak dapat bekerjasama dengan baik dan jujur. Dengan adanya pelaksanaan pajak yang semakin mudah paling tidak akan membuat wajib pajak nyaman dalam melaksanakan kewajiban perpajakannya. Sehingga mampu menekan kemungkinan terjadinya penggelapan pajak dan dapat meningkatkan penerimaan pajak untuk membiayai pembangunan nasional.

Hal ini menunjukkan bahwa untuk lebih mengoptimalkan pelaksanaan self assessment system, diperlukan undang-undang yang menyederhanakan pelaksanaan kewajiban pajak. Selain itu diperlukan pembinaan dan penyuluhan 
perpajakan, sehingga tingkat kesadaran, kejujuran, kemauan untuk membayar dan kedisiplinan wajib pajak terus meningkat. Fungsi utama dari pajak yakni mensejahteraan rakyat secara adil dan merata dapat diperbaiki melalui peningkatan fungsi pengawasan yang ketat dan tegas dari pemerintah dalam mengalokasikan penerimaan pajak untuk pembiayaan atau pengeluaran yang betul-betul dibutuhkan dan bermanfaat bagi masyarakat banyak.

Sedangkan hasil pengujian $\mathrm{H}_{\mathrm{a}}$ sebagaimana disajikan pada tabel 13 menunjukkan bahwa variabel diskriminasi mempunyai tingkat signifikasi sebesar 0,001. Hal ini berarti $\mathrm{H}_{\mathrm{a} 3}$ diterima sehingga dapat dikatakan bahwa diskriminasi berpengaruh signifikan terhadap etika penggelapan pajak. Nilai koefisien bertanda positif artinya semakin tinggi tingkat diskriminasi, maka persepsi wajib pajak mengenai etika penggelapan pajak cenderung dianggap sebagai perilaku yang etis. Semkin banyak bentuk diskriminasi dalam peraturan perpajakan yang berlaku, maka penggelapan pajak merupakan persepsi yagn etis. Sebaliknya semakin rendah tingkat diskriminasi maka penggelapan pajak merupakan persepsi yang tidak etis (Mujiyati dkk, 2017).

Penggelapan pajak dianggap suatu hal yang etis ataupun tidak etis tergantung bagaimana persepsi wajib pajak terhadap diskriminasi dalam pelaksanaan perpajakan. Wajib pajak berpendapat bahwa pemerintah tidak diperbolehkan melakukan diskriminasi dalam bentuk apapun dalam perpajakan. Kebijakan diperbolehkannya zakat sebagai faktor pengurang kewajiban perpajakan dan adanya zona bebas pajak merupakan suatu bentuk diskriminasi karena hanya menguntungkan sebagian kelompok masyarakat saja. Asas persamaan hak bagi warga negara mengakibatkan kecemburuan pada kelompok yang tidak menerima keuntungan dari kebijakan tersebut, yang nantinya akan mengakibatkan tindakan penggelapan pajak. Hasil penelitian ini konsisten dengan penelitian yang dilakukan oleh McGee (2008), Nickerson et al. (2009), Suminarsasi dan Supriyadi (2011) dan Mujiyati dkk, (2017).

Diskriminasi merupakan perlakuan yang tidak seimbang terhadap perorangan, atau kelompok, berdasarkan sesuatu, biasanya bersifat kategorikal, 
atau atribut-atribut khas, seperti berdasarkan ras, kesukubangsaan, agama, atau keanggotaan kelas-kelas sosial. Masyarakat/Wajib Pajak sebagai pihak yang membayarkan pajak dan pemerintah sebagai lembaga tertinggi yang diamanahkan untuk mengelola dana pajak yang ada harus lebih meningkatkan kinerja, mutu, kualitas, disiplin dan integritas tinggi yang berkaitan dengan moral yang dituntut dari setiap aparat Ditjen Pajak dengan bersikap jujur dan bersih dari tindakantindakan tercela yang senantiasa mengutamakan kepentingan negara sehingga masyarakat/Wajib Pajak menjadi senang dan memiliki tingkat kesadaran kepatuhan pajak secara sukarela (voluntary tax compliance) yang tinggi. Oleh karena demikian, maka target penerimaan pajak negara bisa meningkat demi terciptanya pembangunan nasional yang merata.

\section{SIMPULAN}

Berdasarkan hasil analisis data yang telah dilakukan dapat disimpulkan bahwa Keadilan berpengaruh signifikan terhadap persepsi wajib pajak mengenai etika penggelapan pajak. Sehingga semakin tinggi persepsi keadilan, maka semakin etis persepsi wajib pajak mengenai etika penggelapan pajak. Dalam hal ini persepsi keadilan oleh wajib pajak terlihat pada persepsi atas tinggi rendahnya tarif pajak yang berlaku dan pemerintah yang adil dalam penyusunan Undang-Undang Perpajakan. Sistem perpajakan berpengaruh signifikan terhadap persepsi wajib pajak mengenai etika penggelapan pajak. Sehingga semakin baik sistem perpajakan, maka penggelapan pajak dipandang sebagai perilaku yang cenderung etis. Persepsi sistem perpajakan oleh wajib pajak terlihat pada persepsi terkait dengan tarif pajak yang dikenakan oleh wajib pajak sesuai dengan tingkat penghasilan wajib pajak sehingga dapat mewujudkan sistem perpajakan yang adil. Diskriminasi berpengaruh signifikan terhadap persepsi wajib pajak mengenai etika penggelapan pajak. Sehingga semakin tingginya tingkat diskriminasi dalam pelaksanaan perpajakan maka semakin meningkatkan persepsi wajib pajak mengenai etika penggelapan pajak. Persepsi wajib pajak terhadap diskriminasi 
terlihat saat terdapat fasilitas bagi masyarakat yang memiliki NPWP atau tidak memiliki dan pemerintah tidak diperbolehkan melakukan diskriminasi dalam bentuk apapun di perpajakan.

Terdapat beberapa keterbatasan dalam penelitian ini, yaitu penelitian ini hanya dilakukan pada wajib pajak di KPP yang terdaftar pada Kantor Wilayah Daerah Istimewa Yogyakarta dan beberapa KPP yang terdaftar di Kantor Wilayah Jawa Tengah II. Pengukuran instrumen dalam penelitian ini menggunakan kuesioner, sehingga ada kemungkinan responden menjawab pertanyaan dengan tidak teliti dan jujur.

Hasil menyatakan bahwa keadilan, sistem perpajakan, dan diskriminasi sangat penting dalam mengurangi penggelapan pajak pada wilayah Yogyakarta dan Jawa Tengah maka perlu adanya analisa dan tindaklanjut mengenai keadilan, sistem perpajakan, dan diskriminasi, dengan demikian peneliti akan memberikan beberapa saran.

Bagi Direktorat Jenderal Pajak, (1) Perlu adanya upaya dari Direktorat Jenderal Pajak untuk meningkatkan kepatuhan Wajib Pajak untuk senantiasa berinovasi dan adil dalam menentukan kebijakan sehingga pembayar pajak dapat menerima kebijakan tersebut sebagai sesuatu yang menstimulus masyarakat bisa sadar membayar pajak berkaitan maraknya kasus penggelapan pajak di berbagai media ; (2) Masih terbatasnya sosialisasi terhadap peraturan-peraturan pajak oleh pihak DJP padahal peraturan tersebut sering berganti. Untuk itu diharapkan DJP untuk menyebarluaskan peraturan-peraturan yang ada manakala terdapat peraturan baru baik peraturan yang menyempurnakan maupun peraturan pengganti. Sehingga informasi tersebut bersifat public good; (3) Perlunya mengadakan program sebagai back up dari ketidakmengertian masyarakat akan manfaat dari pajak yang mereka bayarkan selama ini. Di samping itu, perlu adanya alokasi yang khusus sebagai kontraprestasi terhadap wajib pajak sehingga wajib pajak tahu benar bahwa ia tidak akan pernah rugi membayar pajak pada negara karena pajak yang mereka bayar akan kembali pada rakyat dan untuk meningkatkan kesejahteraan. 
Bagi Peneliti Selanjutnya, (1) Menambah jumlah responden dan wilayah penelitian sehingga menambah sebuah penelitian yang lebih baik; (2) Menambahkan jumlah variabel independen yang dapat mempengaruhi penggelapan pajak; (3) Tidak hanya menggunakan kuesioner tapi juga melakukan wawancara secara langsung; (4) Disarankan untuk menggunakan kuesioner lain yang lebih valid.

\section{PUSTAKA ACUAN}

Abrahams, N.B. dan Kristianto, A.B.2016. Persepsi Calon Wajib Pajak dan Wajib Pajak terhadap Etika Penggelapan di Salatiga. Berkala Akuntansi dan Keuangan Indonesia. Vol. 1 No. 1 pp 50-70.

Andria, Harry. 2008. Aspek Keadilan Pengenaan Pajak Penghasilan Terhadap Transaksi Perdagangan Saham Di Bursa Efek. Tesis, Universitas Indonesia, Jakarta.

Danandjaja, James. 2003. Diskriminasi Terhadap Minoritas Masih Merupakan Masalah Aktual di Indonesia Sehingga Perlu Ditanggulangi Segera.

Hartman, Laura P dan Desjardins. 2008. Business Ethics: Decision Making for Personal Integrity and Social Responsibility. New York: McGraw-Hill

Himawan, Aditya. 2017. Fitra: Setiap Tahun, Penghindaran Pajak Capai Rp110 Triliun. $\quad$ https://www.suara.com/bisnis/2017/11/30/190456/fitrasetiap-tahun-penghindaran-pajak-capai-rp110-triliun diakses tanggal 7 Agustus 2018.

Indriyani, Mila., S. Nurlela dan E.M. Wahyuningsih. 2016. Pengaruh Keadilan, Sistem Perpajakan, Diskriminasi dan Kemungkinan Terdeteksinya Kecurangan Terhadap Persepsi Wajib Pajak Orang Pribadi Mengenai Perilaku Tax Evasion. Prosiding Seminar Nasional IENACO. 
Jogiyanto. 2010. Metodologi Penelitian Bisnis: Salah Kaprah dan PengalamanPengalaman. Yogyakarta: BPFE-Yogyakarta.

Kurniawati, Melliana dan Toly, Agus Rianto. 2014. Analisis Keadilan Pajak, Biaya Kepatuhan dan Tarif Pajak terhadap Persepsi Wajib Pajak Mengenai Penggelapan Pajak di Surabaya Barat. Tax \& Accounting Review. Vol. 4 No. 2 pp. 1-12.

Mardiasmo. 2009. Perpajakan Edisi Revisi 2009. Yogyakarta: Penerbit Andi.

Mardiasmo. 2011. Perpajakan Indonesia. Yogjakarta: Andi.

McGee, Robert W. 2006. Three Views on the Ethics of Tax Evasion. Journal of Business Ethics 2006, pp. 15-35.

McGee, Robert.W., Simon dan Annie. 2008. A comparative Study on Perceived Ethics of Tax Evasion: Hong Kong Vs the United State., Journal of Business Ethics Vol. 77 No. 2 pp. 147-158.

Mujiyati, F. R. Rohmawati dan W. H. Ririn. 2017. Determinan Persepsi Mengenai Etika atas Penggelapan Pajak (Tax Evasion). Riset Akuntansi dan Keuangan Indonesia. Vol. 3 No. 1 pp. 1-12.

Nickerson, Inge. 2009. Pleshko dan McGee. Presenting the Dimensionality of An Ethics Scale pertaining To Tax Evasion. Journal of Legal, Ethical and Regulatory Issues, Volume 12 No. 1.

Palil, M. R., M.M. Malek dan A. R. Jaguli. 2016. Issues, Challenges and Problem with Tax Evasion: The Institutional Factors Approach. Gadjah Mada International Journal of Business. Vol. 18 No. 2 pp. 187-206.

Rahayu, Siti Kurnia. 2010. Pajak dan Perpajakan. Perpustakaan FEB.Yogyakarta: Graha Ilmu. 
Setiawan, Maria Justina. 2008. Sekilas Tentang Manajemen Pajak. Jurnal Administrasi Bisnis. Vol. 4 No. 2 pp. 174-178.

Siahaan, Marihot P. 2010. Hukum Pajak Material. Yogyakarta: Penerbit Graha Ilmu.

Suminarsasi, Wahyu dan Supriyadi. 2011. Pengaruh Keadilan, Sistem Perpajakan dan Diskriminasi Terhadap Persepsi Wajib Pajak Mengenai Penggelapan Pajak.Yogyakarta, PPJK 15 Universitas Gajah Mada.

Undang-Undang Nomor 39 Tahun 1999 tentang Hak Asasi manusia.

Undang-Undang Nomor 16 Tahun 2009 tentang Perubahan Atas Undang-Undang Nomor 6 Tahun 1983 Tentang Ketentuan Umum dan Tata Cara Perpajakan.

Velasquez, Manuel G. 2002. Business Ethics: Consepts and Cases Fift Edition. New Jersey: Pearson Education.

Widjaja, P. N. K., L. Lambey dan S. K. Walandouw. 2017. Pengaruh Diskriminasi dan Pemeriksaan Pajak Terhadap Persepsi Wajib Pajak Orang Pribadi Mengenai Penggelapan Pajak di Kota Bitung. Jurnal Riset Akuntansi Going Concern. Vol. 12 No. 2 pp. 541-552.

Zain, Muhammad. 2008. Manajemen Perpajakan Edisi 3. Jakarta: Salemba Empat. 